Vol. 06, No. 04; 2021

ISSN: $2456-8643$

\title{
CHARACTERISTICS OF MAERUA CRASSIFOLIA FORSK., A WOODY SAHELIAN FORAGE IN THE SOGOBE FOREST RESERVE IN FERLO, SENEGAL
}

\author{
Sékouna DIATTA, Mame Aminata Diop FOFANA, Amy BAKHOUM, Eric KALY, Oumar SARR, Moustapha \\ Bassimbe SAGNA, Daouda NGOM and Aliou GUISSE \\ Cheikh Anta Diop University, Department of Plant Biology, laboratory of Plant Ecology and Eco-hydrology, BP: \\ 5005 Fann, Dakar-Senegal
}

https://doi.org/10.35410/IJAEB.2021.5648

\begin{abstract}
In the Sahelian zone, particularly in the pastoral zone, woody fodder occupies an important place in the life of the populations. Livestock, the main economic activity, is extensive. For much of the year (dry season), it relies on woody fodder. A good knowledge of these forage woody plants in all their aspects, namely ecology, nutritional quality, regeneration potential, is necessary for the mastery of this sector. Maerua crassifolia Forks is one of these forage species found in northern Ferlo in Senegal. A vegetation survey was made with 32 plots, each of them having an area of $2500 \mathrm{~m}^{2}(50 \mathrm{~m} \times 50 \mathrm{~m})$. Maerua crassifolia being rare in the area, the choice of plots was guided by its presence. Whenever an individual of this species is encountered, it forms the center of a plot. Dendrometric and phytosociological parameters are measured. The results show that the actual density of Maerua crassifolia (4 individuals.ha-1), compared to that of the woody stand (79 individuals.ha-1), is very low in this area. Its population has a shrub structure with a very low regeneration rate $(0.32 \%)$. Maerua crassifolia is accompanied by 4 species: Boscia senegalensis, Balanites aegyptiaca, Acacia raddiana and Adenium obesum. Boscia senegalensis is by far the most common species next to Maerua crassifolia based on the frequency of occurrence analysis. With above results, Maerua crassifolia should be subjected to more care in ecosystem restauration strategies.
\end{abstract}

Keywords: Sahelian zone, forage, Maerua crassifolia, Senegal, Ferlo, companion species.

\section{INTRODUCTION}

In the Sahelian zone, livestock feed is mainly based on natural pastures. The year is characterized by two (2) seasons, a rainy season, and a dry season. The rainy season, the period during which the herbaceous vegetation appears and develops, is short-lived (about 3 to 4 months). This temporary availability of herbaceous fodder has led livestock to fall back on woody plants, which will thus provide most of their food during the long dry season. Faced with such a situation, woody fodder has since taken an important place in research activities. This research has focused on characterizing many aspects of these forage woody plants. The results showed that their perennial nature is of capital importance in a highly arid environment. The constant availability of this woody fodder is linked to the diversity of species and their phenologies differentiated in time and space ([18], [19] and [32]) unlike herbaceous species. Woody vegetation provides not only aerial fodder, which constitutes the bulk of livestock feed during the 
lean season [22], but also shade [2] on the soil, grass cover, animals, and people. Their major interest is to provide proteins, vitamins and often mineral elements which are lacking in herbaceous pastures during the dry season, because they are in the state of straw [22]. Forage woody plants help optimize rumen functioning [15]. In terms of ethnobotany and uses, these species are well known [21] and [37]. Aside from their fodder role, these species are used by humans, for fuelwood production, for their fruits and bark, for their role in soil fixation, or for other social and cultural functions. However, the types of use often depend on the ethnic group considered and on the ancestral customs developed in each country [8]. Studies have shown that on rangelands, the presence of woody fodder improves production (from 5 to $12 \%$ depending on the route and by $25 \%$ on average) and the quality parameters of the herbaceous layer (specific richness, pastoral value, nutrients, etc.) [5]. In Senegal, particularly in Ferlo, which is a sylvopastoral zone, it goes without saying that forage woody plants play a fundamental role in feeding livestock but also in the life of the populations. Many studies have been carried out there, with the aim of knowing the dynamics of vegetation because it depends on the sustainability of the pastoral system. Among the many studies carried out in Ferlo, we can cite among others those of [35], [1], [36], [22], [13], [12] ... So, it appears that a good knowledge of the woody forage species in the area is essential. This is the framework for the present study, which aims to determine the characteristics of de Maerua crassifolia Forsk. in the Sogobe sylvopastoral reserve. It is particularly a question of (i) evaluating the current state of the population of Maerua crassifolia in this part of the sylvopastoral zone to deduce its structure and (ii) establishing the "sociogram" of this species and identifying and characterizing the species that are associated with it.

\section{MATERIALS AND METHODS}

\subsection{The study area}

The study was carried out in the Sogobe sylvopastoral reserve in the North of Ferlo, near Souilène (Keur Mor Ibra) whose geographical coordinates are $16^{\circ} 21$ 'North and $15^{\circ} 26^{\prime}$ 'West (Figure 1). Administratively, Keur Mor Ibra is in Mbane commune, Bokhol district, Dagana department and Saint-Louis region. From a climatic point of view, the study area is in the vast semi-desert sylvopastoral space of northeastern Senegal called the Ferlo circumscribed in the heart of the West African Sahelian zone. It is a very sensitive area from a hydroclimatic point of view given the very high interannual and spatial variability of precipitation. 


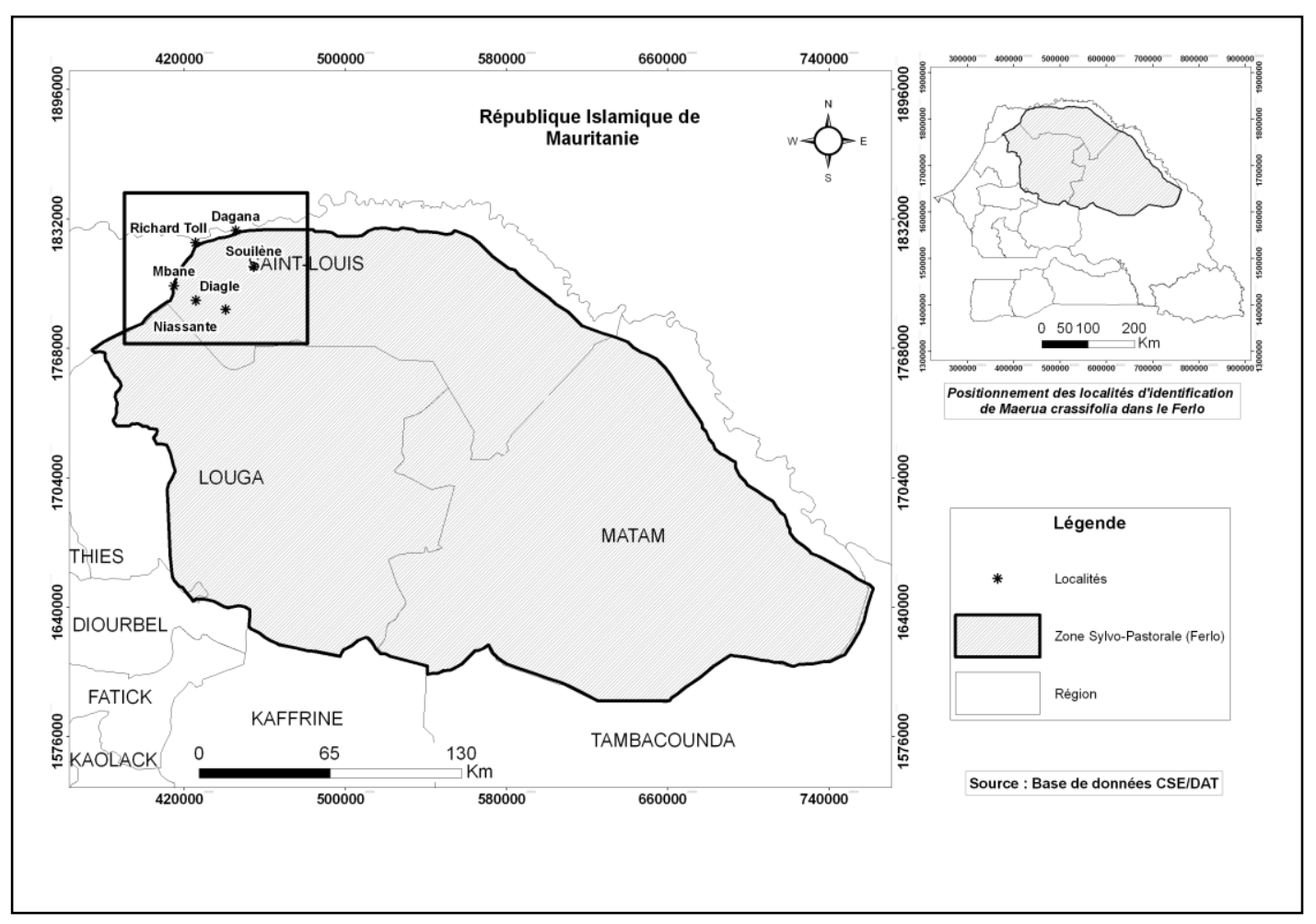

Figure 1 : Situation map of the study area

Annual precipitation is about $300 \mathrm{~mm} /$ year. Harmattan contributes to soil erosion and desertification, further exacerbated by droughts such as those of 1973 and 1983-84. This climate is characterized by the distinction of the year in two seasons: a rainy season from July to September and a dry season from October to June. Geomorphologically, the Ferlo Nord-Senegal region belongs to sand dune formations and is characterized by a set of asymmetric ridges separated by longitudinal depressions with grayish sandy clay soil locally calcareous and hydromorphic soil with temporary waterlogging [25]. The soils, subarid reddish brown, are neutral to weakly acidic $(5.8<\mathrm{pH}<7.2)$ with 90 to $95 \%$ coarse sand and 3 to $5 \%$ clay in the upper layers on the one hand and 80 to $90 \%$ sand, 8 to $10 \%$ clay in the lower layers on the other hand [16]. They are poor in organic matter. The natural vegetation is of the shrub-steppe type [23] composed of thorny trees, shrubs, and annual grasses. The woody cover is $30 \%$ [2]. The shrub population is characterized by a predominance of Boscia senegalensis and Balanites aegyptiaca. The herbaceous layer, in the form of a continuous layer which can reach $50 \mathrm{~cm}$ to 1 $\mathrm{m}$ in height, is dominated by annual species, in particular grasses, generally with narrow, folded or rolled blades (Schoenefeldia gracilis, Aristida stipoides, Cenchrus biflores, Chloris prieusi) [4]. The population density is low with less than 8 inhabitants $/ \mathrm{km}^{2}$ in 1995 (TOURE et al., 1997). This low density can be explained by waves of emigration; it also finds its explanation in the great drought of the 1970 s which forced young people to seek work in urban centers. The 
population is mainly composed of Peulhs (85\%), Moors and Wolofs [30]. The main activity in this area of Ferlo is extensive livestock farming, therefore livestock farming essentially based on natural pastures. This breeding is highly dependent on climatic hazards. It is characterized by the extreme mobility of the breeders who are always in search of fodder and water points. This fodder whose availability, in time (duration of pastures) as in quantity and quality, decreases more and more because of the rainfall irregularity from one year to another, to this is added a general decrease in the average's rainfall. As a result, nowadays, the scarcity of natural resources is an undisputed reality in Ferlo. The local cattle herd is made up of Gobra or Bos indicus zebus; it is a very homogeneous breed animal adapted to the difficult conditions of the Sahelian zone. In terms of the sheep herd, the Fulani-Fulani breed predominates [31]. Next to livestock, there is agriculture which is limited to the cultivation of cereals for own consumption. It is essentially based on the cultivation of millet in the rainy season and on small areas.

\subsection{Materials}

During the field study, the use of several equipment was necessary for data collection. This is a GPS (Global Positioning System) for recording the geographic coordinates of plots; tape meters for the delimitation of the plots, the measurement of the circumferences $(0.30$ and $1.30 \mathrm{~m})$, the distance between the trees; stakes to delimit the plots; a graduated pole for measuring the height of the trees; floristic survey sheets for entering field data and a hammer for securing the stakes.

\subsection{Methods}

\subsubsection{The choice of plots}

Maerua crassifolia Forks being rare in the area, the choice of plots was guided by its presence. Whenever an individual of this species is encountered, it forms the center of a plot, and its geographic coordinates are taken. When several individuals of $M$. crassifolia are close, the one with the greatest height is chosen as the center of the plot.

\subsubsection{Methods of woody stand study}

\subsubsection{Vegetation surveys}

Each plot has an area of $2500 \mathrm{~m}^{2}(50 \mathrm{~m} \times 50 \mathrm{~m})$ and has been defined by the 3-4-5 method which allows to have a square. The survey area as said above is centered on a base of Maerua crassifolia individual. Thus in each plot, an exhaustive count of the woody population was made, the floristic list was established on the basis of the Flora of Senegal [7], for each tree, the following parameters were measured: the total height; the circumference at $0.30 \mathrm{~m}$ (justified by the fact that the individuals in this zone have very low ramifications [2]) which makes it possible to establish the basal cover and the structure of the stand according to circumference classes; the distance between two individuals using the nearest individual method (P.P.I.) to assess the distribution of individuals; the distance between individuals of Maerua crassifolia and those of other species to know which are the companion species; crown diameter by simulating its vertical projection on the ground using a tape measure to assess coverage. The aerial cover of a tree is the proportion of soil that would be shaded by the leaves and branches of woody plants 
(SKERMANN, 1998). For this, the average of the north-south and east-west distance is taken. Also, in each plot, dead individuals and seedlings were counted.

\subsubsection{Woody vegetation parameters}

Coverage was appreciated through aerial cover and basal area.

$>$ The aerial cover corresponds to the proportion of the surface occupied by the vertical projection on the ground of the crown of a woody tree (ROBERTS-PICHETTE and GILLESPIE, 2002). It is expressed in square meters per hectare $\left(\mathrm{m}^{2} / \mathrm{ha}\right)$. For an individual, this is the portion of the ground covered by its foliage. The aerial cover is calculated, with the formula below:

$$
\mathrm{C}=\frac{\sum \pi\left(\frac{\mathrm{d}_{\mathrm{mh}}}{2}\right)^{2}}{\mathrm{~S}_{\mathrm{E}}}
$$

where $\mathbf{C}=$ aerial cover; $\mathbf{d m h}=$ average crown diameter in $\mathrm{m}$, which is equal to half the sum of the North-South and East-West diameters; $\mathbf{S E}=$ area of the sample considered in ha.

The aerial cover of a species is equal to the sum of the aerial cover of all its individuals. Also, for a woody stand, it is the sum of the aerial cover of all the individuals that make it up.

The basal area refers to the proportion of the area of a sample occupied by the anchoring area (evaluated at the base) of an individual, a species, or a stand (ROBERTSPICHETTE and GILLESPIE, 2002). It is thus expressed in square meters per hectare $\left(\mathrm{m}^{2} \cdot \mathrm{ha}^{-1}\right)$. For an individual, it is the ratio between the area of the cross section of its trunk at $0.30 \mathrm{~m}$ from the ground and the area of the sample considered. It is therefore obtained from the following formula:

$$
\mathrm{St}=\frac{\sum \pi\left(\frac{\mathrm{d} 0,3}{2}\right)^{2}}{\mathrm{~S}_{\mathrm{E}}}
$$

With $\mathbf{S t}=$ basal area; $\mathbf{d}=$ diameter in $\mathrm{m}$ of the trunk at $0.3 \mathrm{~m}$ from the ground, obtained by dividing the circumference measured at this height by $\pi ; \mathbf{S E}=$ area of the sample considered in ha.

The basal area of a species is the sum of the basal areas of all its individuals. Also, for a stand, it is the sum of the basal areas of all the individuals that make it up. It therefore depends on the density and size of the feet.

$>$ The density of a species is the number of plants belonging to the species per unit area. It is expressed in number of individuals per hectare (ind./h). This density was determined in two different ways:

- The actual or observed density is given by the ratio of the total population to the sampled area.

$$
\text { Dob. }=\frac{N i}{S}
$$


where Dob. $=$ Observed density; $\mathrm{Ni}=$ total number in the sample considered and $\mathrm{S}=$ sample area in ha.

- The theoretical density is the ratio of the area of one hectare $\left(\right.$ in $\left.^{2}{ }^{2}\right)$ to the square of the average distance between trees.

$$
\text { Dth. }=\left(\frac{100}{\mathrm{dm}}\right)^{2}
$$

Where $\mathrm{Dth}=$ theoretical density; $\mathrm{Dm}=$ average distance between trees

The relative density of a species corresponds to the proportion of individuals of a species compared to individuals of all species. It is equal to the number of a species out of the total number of the sample multiplied by 100 :

$$
\operatorname{Dr}=\frac{N i}{N} \times 100
$$

Where $\mathrm{Dr}=$ Relative density; $\mathrm{Ni}=$ number of a species; $\mathrm{N}=$ total sample size.

$>$ The exploitation rate of the woody population is the ratio (in percentage) of the number of trees exploited divided by the total number of trees.

$$
\text { TEP }=\frac{\text { Number of trees exploited }}{\text { Total population sizes }} \times 100
$$

The regeneration rate of the woody population is given by the ratio between the total number of young plants and the total number of plants in the woody population (POUPON, 1980).

\section{Total number of seedlings$$
\mathrm{TRP}=\longrightarrow \times 100
$$ \\ Total population size}

The specific importance of regeneration is obtained from the percentage ratio between the number of young plants of a species and the number of young plants counted. (AKPO \& GROUZIS, 1996) .

$$
\text { ISR }=\frac{\text { Number of seedlings of a species }}{\text { Total number of young plants counted }} \times 100
$$

Relative frequency refers to the distribution of a species relative to the distribution of all species in the sample. It is given by the percentage ratio between the frequency of the species in question and the total frequency of all the species in the sample.

$$
\text { Fri }=\times 100 \frac{F i}{F}
$$

With $\mathbf{F r}=$ relative frequency expressed as a percentage (\%);

$\mathbf{F i}=$ frequency of presence of species $\mathrm{i}$

$\mathbf{F}=$ sum of the frequencies of all species in the sample.

\subsubsection{Vegetation structure}


The vegetation structure is based on the definition of height and circumference classes. For this, the distribution of individuals was studied through height classes in meters (]0.5-2,5]; ]2,5-5] ; ]5-7,5] ; ]7,5-10] ; ]10-12,5]), then through circumference classes (]0,1-0,5]; ]0,5-1] ;] 1-1,5] ;] $1,5-2]$ and $>2 \mathrm{~m}$ ).

\subsubsection{Homogeneity of the woody stand}

To assess the degree of homogeneity of the woody stand, we subjected the matrix of 5 species $x$ 32 surveys to a Factor Analysis of Correspondences (AFC). The AFC is a computerized sorting method used to group taxa or sites with similar attributes. Being a multivariate method, it preserves the identity of species and is generally considered more sensitive for the detection of changing patterns in communities. It makes it possible, more than diversity indices, to detect the expected effects more quickly (GRAY et al. 1990), cited by [17].

\subsubsection{Data analysis}

The statistical processing of the data is done with the EXCEL 2007 spreadsheet and the Minitab software. A total of 32 plots of 2,500 $\mathrm{m}^{2}$ were studied, ie a total area of 8 ha.

\section{RESULTS}

\subsection{Floristic diversity}

Five woody species have been identified. They are divided into 5 genera belonging to 4 families. The family of Capparaceae is represented by two species (Boscia senegalensis and Maerua crassifolia) while those of Apocynaceae (Adenium obesum), Fabaceae (Acacia raddiana) and Balanitaceae (Balanites aegyptiaca) have each a single species (Table 1). 
Table 1: study area taxonomic groups

\begin{tabular}{|l|l|l|}
\hline Families & Genres & species \\
\hline Apocynaceae & Adenium & Adenium obesum Roem \&Schult \\
\hline \multirow{3}{*}{ Capparaceae } & Boscia & Boscia senegalensis (Pers.) Lam. ex Poir \\
\cline { 2 - 3 } Faerua & Maerua crassifolia Forsk. \\
\hline Fabaceae & Acacia & Acacia raddiana Savi /tortilis (Forsk.) Hayne \\
\hline Balanitacées & Balanites & Balanites aegyptiaca (L.) \\
\hline
\end{tabular}

\subsection{Vegetation characteristics}

\subsubsection{Relative density and frequency of occurrence}

Boscia senegalensis is the most representative (abundant) species with 436 individuals or a relative density of $69.1 \%$ (Table 2). It is followed by Balanites aegyptiaca with 112 individuals, or $17.7 \%$ of the total population. Then follow Acacia raddiana and Maerua crassifolia with respectively 47 individuals, or $7.75 \%$ and 35 individuals, or 5.5\%. Adenium obesum represents only $0.15 \%$ of the population size.

Maerua crassifolia has a frequency of occurrence of $100 \%$ because of the survey method. Boscia senegalensis and Balanites aegyptiaca have a frequency of $97 \%$ and $71 \%$, respectively. So, their frequency being greater than 50\%, they are constant species [9].

Table 2: Population and species characteristics in the Sogebe Reserve

\begin{tabular}{|l|l|l|l|l|l|l|}
\cline { 2 - 9 } \multicolumn{1}{c|}{} & Pop. & B. $a$. & $M$ c. & B. $s$. & A. $r$. & A. \\
\hline Total individuals & 631 & 112 & 35 & 436 & 47 & 1 \\
\hline Relative density (\%) & 100 & 17.75 & 5.55 & 69.10 & 7.45 & 0.15 \\
\hline Centesimal frequency [of occurrence] (\%) & - & 71 & 100 & 97 & 40 & 3.10 \\
\hline Actual density (individuals/ha) & 79 & 14 & 4 & 55 & 6 & - \\
\hline Theoretical density (individuals/ha) & 204 & 33 & 29 & 21 & 29 & 30 \\
\hline $\begin{array}{l}\text { Average distance from Maerua crassifolia } \\
\text { (m) }\end{array}$ & $7^{*}$ & 17.36 & 26.85 & 18.76 & 18.62 & 18.20 \\
\hline Aerial cover rate (\%) & 5.02 & 2.26 & 0.54 & - & 2.22 & - \\
\hline Regeneration (\%) & 1.26 & 0.47 & 0.32 & - & 0.47 & - \\
\hline Exploitation rate & 1.42 & 0.79 & - & - & 0.63 & - \\
\hline
\end{tabular}

Pop.: Population; B.a.: Balanites aegyptiaca; M. c.: Maerua crassifolia; B. s.: Boscia senegalensis; A. r.: Acacia raddiana; A. o.: Adenium obesum: very small or none; *: average distance between individuals in the woody population.

\subsubsection{Woody population density}

The current density is equal to 79 individuals/ha with a clear variability between species (Table 2). Thus, Boscia senegalensis has the highest density with 54 individuals/ha, followed by Balanites aegyptiaca with 14 individuals/ha, finally Acacia raddiana and Maerua crassifolia respectively 4 and 5 individuals/ha. On the other hand, the theoretical density of the population is 204 individuals/ha, which is 2.6 times the actual density. 


\subsubsection{Woody cover}

The aerial cover varies greatly depending on the surveys. It varies from 0.061 to $310.86 \mathrm{~m}^{2} / \mathrm{ha}$. The total arial woody cover is $502 \mathrm{~m}^{2} / \mathrm{ha}$, or $5.02 \%$ (Table 2). This value varies by species. Indeed, the most important specific recovery is observed with Balanites aegyptiaca with a total recovery of $226 \mathrm{~m}^{2}$ / ha or $2.26 \%$, then come Acacia raddiana with a value of $222 \mathrm{~m}^{2} /$ ha or $2.22 \%$ and Maerua crassifolia with $54 \mathrm{~m}^{2} /$ ha or about $0.54 \%$. The basal cover is very low for both the woody stand and the species.

\subsubsection{Regeneration and Exploitation}

Regeneration and exploitation rate are presented in Table 2. Regeneration is $1.26 \%$. Balanites aegyptiaca and Acacia raddiana have the same regeneration rate, $(0.47 \%)$, followed by Maerua crassifolia with $0.32 \%$. Boscia senegalensis and Adenium obesum does not present seedlings. For the exploitation rate, it is $1.42 \%$ for the population. Balanites aegyptiaca and Acacia raddiana are the only exploited species found in the field, with Balanites aegyptiaca having the highest rate $(0.79 \%)$.

\subsection{The vegetation structure}

\subsubsection{The height Variation}

The distribution of the woody population based on the height classes is of unimodal type. Individuals are distributed in all height classes considered for the entire stand (Figure 2). The height classes $] 2.5-5 \mathrm{~m}]$ and $] 5-7.5 \mathrm{~m}]$ concentrate the most individuals with more than three quarters of the total number (77\%). This same distribution is noted for all the species considered except for Acacia raddiana where the individuals tend to group in the height classes ]5-7.5m] and $] 7.5-10 \mathrm{~m}]$. In addition, the populations of Maerua crassifolia and Balanites aegyptiaca have the same distribution of their individuals. It should be noted that the largest trees (]10-12.5m]) are found in the population of Acacia raddiana, but they represent a low rate (5\%).
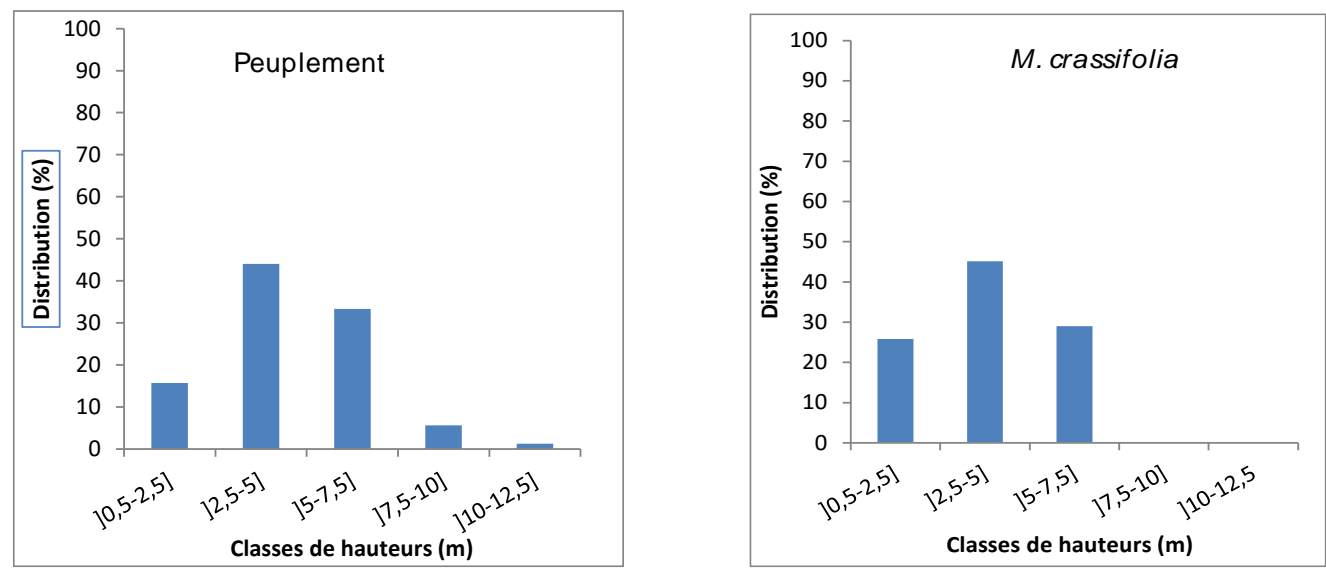

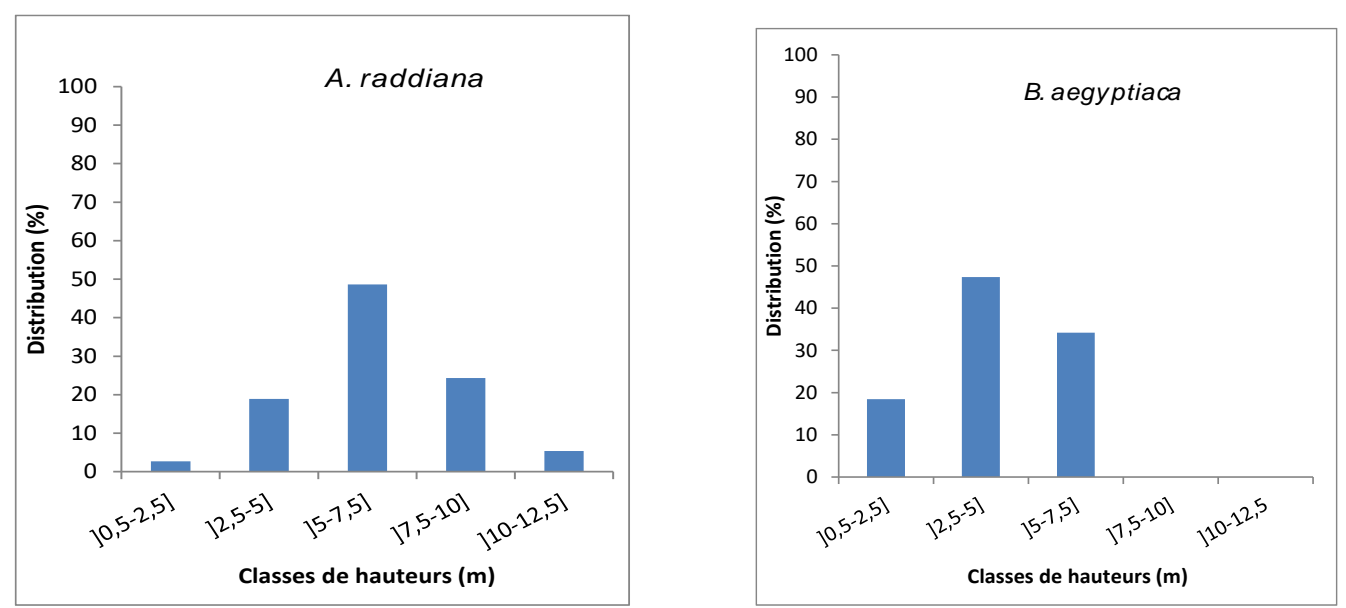

Figure 2: Distribution of individuals from the stand of Maerua crassifolia, Acacia raddiana and Balanites aegyptiaca according to height classes.

\subsubsection{The Circumference Variation}

The circumference of individuals has a significant variation ranging from $10 \mathrm{~cm}$ to $165 \mathrm{~cm}$. The Figure 3 shows the distribution of trunks according to the circumference classes. The first two classes include more than $80 \%$ of individuals with a dominance of the second class (] $0.5-1 \mathrm{~m}]$ ) which holds the highest percentage, 50\%. Regarding the specific distribution in circumference classes, Maerua crassifolia and the stand have a similar trend. Balanites aegyptiaca individuals are distributed only in the first three classes. The distribution of Acacia raddiana is quite different. Unlike the first two species, the individuals of Acacia raddiana are concentrated in the second and third classes (] $0.5-1 \mathrm{~m}]$ and ] $1-1.5 \mathrm{~m}])$, with a peak in the third class (] $1-1.5 \mathrm{~m}])$. Note that it is mainly in the population of Acacia raddiana that we found the largest individuals (]1.5$2 \mathrm{~m}]$ ) of the stand but they represent a low rate (5\%).
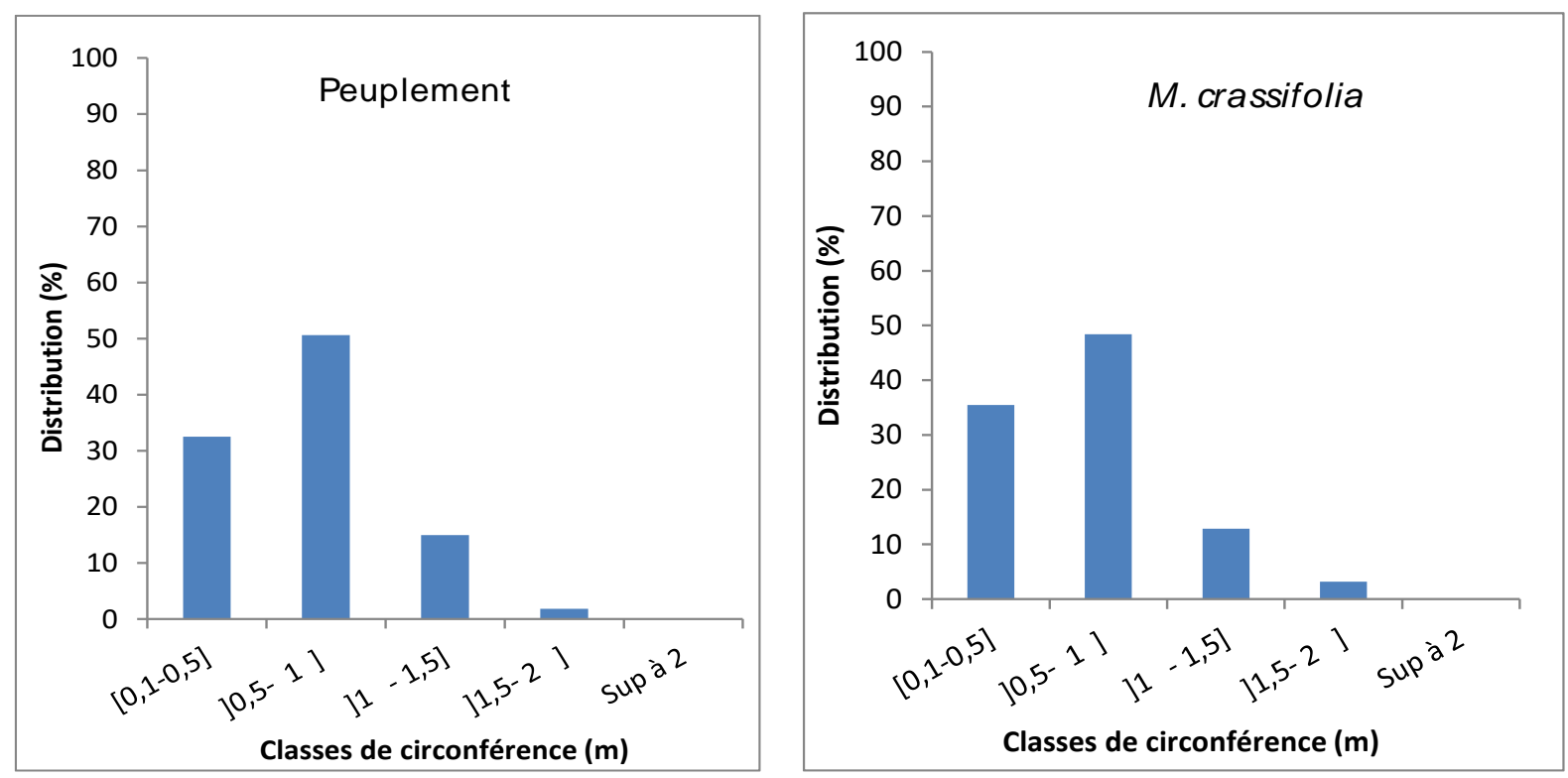

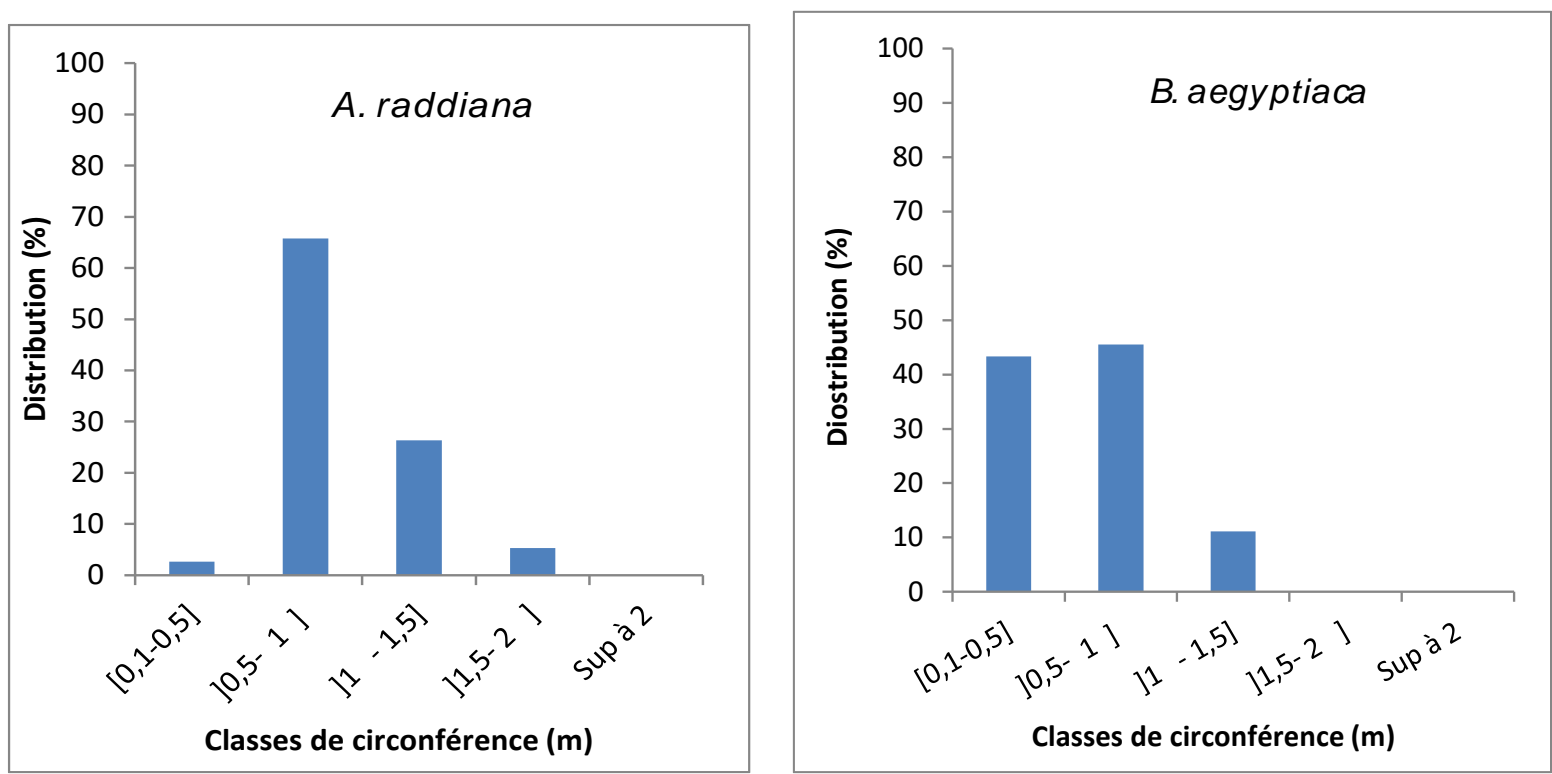

Figure 3: Distribution of individuals of the stand, Maerua crassifolia, Acacia raddiana and Balanites aegyptiaca according to the classes of circumference.

\subsection{Homogeneity of the stand}

\subsubsection{Average distance $(\mathrm{m})$ of other species from Maerua crassifolia}

The average distance between two trees is $7 \mathrm{~m}$ with a coefficient of variation of $17.03 \%$ (Table 2). The average distances between the individuals of Maerua crassifolia and those of other species varies slightly according to the species: Balanites aegyptiaca is the closest species (17.36 $\mathrm{m})$ and Maerua crassifolia $(26.85 \mathrm{~m})$, the most distant species. The small standard deviations obtained indicate a low dispersion around the means. Regardless of the species, these distances are very high, which indicates that the different individuals of the species associated with Maerua crassifolia are very distant while the average distance between the individuals of the stand is $7 \mathrm{~m}$.

\subsubsection{Spatial distribution}

The matrix of 5 species x 32 surveys was submitted to the Correspondence Analysis (CA) to assess the degree of homogeneity of the population. The eigenvalues and inertias of the main axes from the CA are presented in table 3 below.

Table 3: Eigenvalues (bits) and inertia (\%) of the 4 axes of the CA.

\begin{tabular}{|l|l|l|l|l|}
\hline \multicolumn{1}{|c|}{ AXES } & F1 & F2 & F3 & F4 \\
\hline Statistics & & & & \\
\hline Inertia (\%) & 0.251 & 0.164 & 0.070 & 0.004 \\
\hline Cumulative inertia (\%) & 51.19 & 33.57 & 4.30 & 0.94 \\
\hline
\end{tabular}


It appears that the 4 axes provide all the information of the matrix. F1 and F2 axes 2 account for most of the total information (84.76\%). Thus, these two axes will define the main plane in which the graphic representation will be made (Figure 4).

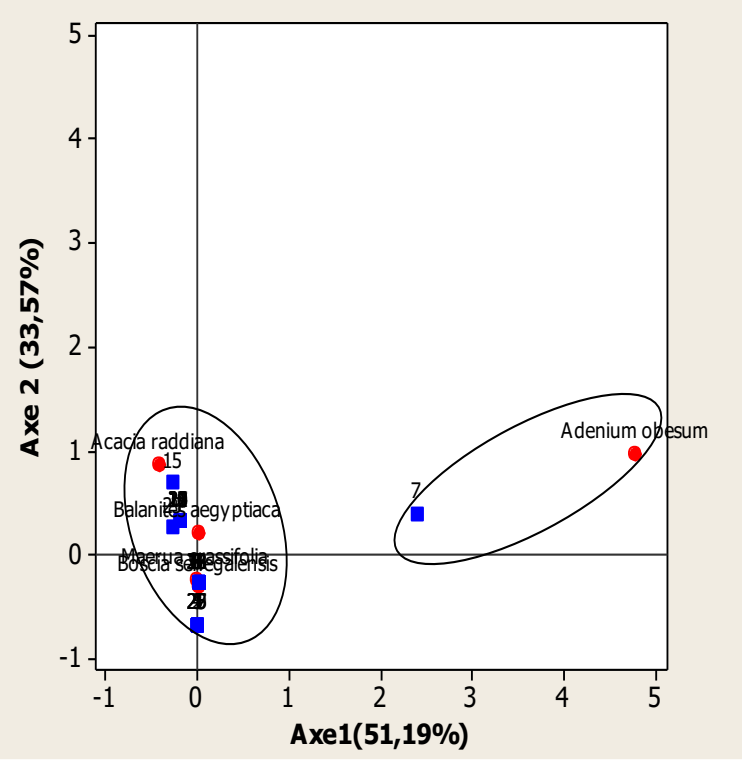

Figure 4: Results of the matrix of 5 species $x 32$ surveys CA recorded along the F1 and F2 axes.

The contribution of species and surveys $(\mathrm{S})$ varies from 0 to $0.91 \%$. Each species provides an average of $0.2 \%$ of the information in the table, compared to $0.03 \%$ per survey. For axis 1 , only the survey 7 has a high contribution $(0.91 \%)$, in the positive $\mathrm{x}$-coordinates as opposed to the rest of the readings with a low contribution in both positive and negative $\mathrm{x}$-coordinates. Only one species is strongly correlated with this factor, Adenium obesum $(r=0.95)$. This axis seems to contrast the records characterized by the presence of Adenium obesum with those characterized by its absence. Indeed, on the 32 surveys, Adenium obesum is present on only one survey (S7). Axis 1 is therefore an axis of decreasing occurrence of species associated with Maerua crassifolia. It defines an axis of abundance of Adenium obesum. As for axis 2, the analysis shows that the records that contribute strongly to the positive y-coordinates to the formation of this axis are: S7 and S15 (to be specified that S7 is in the positive coordinate quadrant while S15 is in the positive ordinate and negative $\mathrm{x}$-axis quadrant) as opposed to the readings with strong contributions in the negative y-coordinates: S1, S2, S3, S4, S5, S25, S26, S27 and S29. The three species [Boscia senegalensis $(\mathrm{r}=0.83)$, Maerua crassifolia $(\mathrm{r}=0.78)$ and Acacia raddiana $(\mathrm{r}=$ $0.73)]$ are in descending order strongly correlated with this axis. Thus, axis 2 seems to oppose the high-contribution surveys of Boscia senegalensis from the other high-contribution surveys of Balanites aegyptiaca and Acacia raddiana. One can note that Boscia senegalensis is only absent in one survey (S15). So, axis 2 is also an axis of decreasing occurrence of species associated with Maerua crassifolia in relation to geomorphology. Indeed, Acacia raddiana and Balanites aegyptiaca meet more in the depressions while Boscia senegalensis occurs mainly at the level of the plateaus.

\section{DISCUSSION}


Vol. 06, No. 04; 2021

ISSN: $2456-8643$

Five species belonging to 5 genera and 4 families have been listed in the Sogebe Forest Reserve. This specific wealth does not reflect the specific richness of this sylvopastoral area. Indeed, the observations made in the field as well as the work carried out in this area have shown a greater specific richness. These include those relating to the woody flora of the Katané terroir in FerloNord Senegal, which revealed the presence of 23 species of 18 genera and 13 families (NDIAYE, 2008); the findings of [12] counted 11 species divided into 9 genera and 8 families; those of [33] recorded 17 species grouping 10 families and 14 genera. This low specific richness can be explained by the sampling method, i.e., the delimitation of the plots based on the presence of Maerua crassifolia. Indeed, the study provides more information on the species associated with M. crassifolia in this area of Ferlo.

The analysis of the centesimal frequencies or frequencies of occurrence of the species, apart from that of Maerua crassifolia which is $100 \%$ since having formed the basis of the delimitation of the plots, shows that Boscia senegalensis is the most represented species with a frequency of occurrence (or frequency of presence) of $97 \%$, followed by Balanites aegyptiaca with a frequency of $71 \%$. Thus, these two species constitute the constant species because having a frequency of presence of more than 50\% ([9] cited by [24]). As for Adenium obesum, it is "the rarest or accidental species" (3.1\%).

From the point of view of abundance, Boscia senegalensis also has the highest relative density with $69.1 \%$, followed by Balanites aegyptiaca (17.75\%), Acacia raddiana (7.45\%), Maerua crassifolia (5.55\%) and Adenium obesum (0.15\%) This strong presence of Boscia senegalensis compared to other species can be explained by the fact that it is a species very little grazed in this area yet very appreciated in other countries such as Gourma in Mali (BENJAMINSEN, 1988 cited by [34]) but also very adapted to the ecoclimatic zone.

The current density is 79 individuals/ha. It is by far very low compared to the density observed in1981, which was 376 subjects/ha [26], or to that of DIOUF et al., (1998), which was 149 individuals per hectare. The persistence of the last drought, combined with anthropization and poor ecosystem management has had a significant impact on stand dynamics. The average distance between two trees is $7 \mathrm{~m}$ or a theoretical density of 204 individuals/ha. It is significantly higher than the real density (more than 2 times the real density) because the distribution of the stand is very heterogeneous due to the high variability of the coefficient of variation (17.03\%) associated with the average distance between two trees [3]. This gives a distribution sometimes in groves, sometimes sparse with bare space in the field [10]. Note that some plots (surveys) are much richer in species because they are at the level of the shallows or depressions. Some species such as Balanites aegyptiaca [27] are more concentrated in depressions when there is a water deficit. As for Maerua crassifolia, its low density (5 individuals/ha) is characteristic of the species. Indeed, this species grows in very sparse stands, with densities of the order of 5 to 10 trees per hectare according to [20]. This is not always the case. At the experimental station of Toukounouss in Niger, the trend is quite different. There, Maerua crassifolia has a very high density of 95 individuals per hectare. This makes the species the main source of green fodder in the dry season and gives a special taste to milk [11].

The number of seedlings for all plots is 8 , or only $1.26 \%$ of the woody stand, which implies low regeneration. This does not corroborate the findings of [6], which had noted between 1989 and 1998 an increase in the regenerative power of woody in this area through the development of 
adaptive strategies. So, we can think that the climate changes of the last ten years have defeated these strategists. The area being an overgrazed area (Boscia senegalensis being a characteristic species of grazed areas), animal pressure will be added to the climatic effects. Indeed, during periods of herbaceous fodder deficit, woody stand is very much in demand by livestock ([14]. Grazing pressure will then be exerted preferentially on young subjects, which contributes to increasing their mortality (ACHARD and CHANONO, 1997, cited by [14]).

The exploitation rate, $1.42 \%$ (here only the slaughtered individuals were considered), is too low compared to that noted in the community pasture of Lour Escale (Department of Kaffrine in Senegal) which is more than 50\% [29]. It is also low, compared to that noted in the community pasture of Khossanto (6.63\%) in Kédougou [17]. This low exploitation rate in no way reflects what has been observed on the ground. In fact, some unsampled places showed a strong exploitation on the part of people.

The structure of the stand was established according to the distribution of individuals in classes of height and circumference. The distribution into height classes shows a very high rate $(93 \%)$ individuals with a lower height $(\leq 7.5 \mathrm{~m})$ while woody individuals with a height of more than 10 $\mathrm{m}$ make up less than $2 \%$ of the stand. This shows the importance of the shrub layer. The distribution based on the circumference classes also reveals a high percentage $(83 \%)$ of individuals with a circumference of less than $1.5 \mathrm{~m}$. This also illustrates the importance of the shrub layer.

The aerial cover $\left(502 \mathrm{~m}^{2} \mathrm{ha}^{-1}\right.$, or $\left.5.02 \%\right)$ is very low compared to that of the community pasture of Khossanto $\left(7844.44 \mathrm{~m}^{2} \mathrm{ha}^{-1}\right.$, or $\left.78.45 \%\right)$ noted by [17] and to that of the community pasture of Lour Escale (1149.54 $\mathrm{m}^{2} \mathrm{ha}^{-1}$, or 20.73\%) found by [29]. This cover is very low in comparison with a study made in the same area by [12]. The latter noted an aerial cover of $2238.8 \mathrm{~m}^{2} \mathrm{ha}^{-1}$ for the stand or $22.4 \%$. The $65.2 \%$ of this cover was brought by Acacia raddiana whose population is generally made up of large individuals. Thus, the low overlap noted in this study can be attributed to the low proportion of large individuals.

The average distance between two individuals and that between the individuals of Maerua crassifolia and those of other species are very indicators of the state of the environment. The very high values of these parameters indicate a degradation of the environment which is confirmed by the massive presence of Boscia senegalensis. Indeed, Boscia senegalensis is a species characteristic of degraded areas. The degree of homogeneity of the woody stand is assessed based on the calculation of the average distances of the species from Maerua crassifolia. From the analysis of the average distances between individuals of Maerua crassifolia and those of other species, it appears that there is no difference. However, one observation is noted examining the correspondence analysis carried out between the 32 surveys and the 5 species. These results have identified two groups: the group of Adenium obesum and that of Boscia senegalensis, Maerua crassifolia, Balanites aegyptiaca and Acacia raddiana. The latter group can be subdivided into two subgroups: the subgroup containing Maerua crassifolia and Boscia senegalensis and that containing Balanites aegyptiaca and Acacia raddiana. It therefore appears that Boscia senegalensis is the species that most shares the ecological area with Maerua crassifolia. These two species are of the same family (Capparaceae). 
Vol. 06, No. 04; 2021

ISSN: $2456-8643$

\section{CONCLUSION}

This study characterized the population of Maerua crassifolia as well as the flora and woody vegetation associated with this species in this northern part of the Ferlo in Senegal. Around Maerua crassifolia, the flora is very little diversified. It is rich in 5 species belonging to 4 genera. The most frequent and the most abundant species is Boscia senegalensis followed by Balanites aegyptiaca and Acacia raddiana. Adenium obesum is the "rarest species". The regeneration of the stand is very low with a renewal rate of $1.26 \%$. The structure of the stand based on both the height and the circumference reveals the importance of the shrub layer. This study also shows a population of Maerua crassifolia with a very low density (5 individuals/ha), but which is nevertheless characteristic of the species. The low rate of regeneration as well as the low densities and very high distances between the trees demonstrate the state of degradation of the ecosystem. The calculation of the average distances between the individuals of Maerua crassifolia and those of other species as well as the CA reveal a close link between Maerua crassifolia and Boscia senegalensis (both species belong to the Capparaceae family). Boscia senegalensis is followed by Balanites aegyptiaca and Acacia raddiana. In perspective, it would be important (i) to study in detail the population of Maerua crassifolia (including its potential regeneration) in Senegal to better establish its "sociogram" and (ii) to develop a management plan, exploitation and integration of this forage woody species in the agrosylvopastoral systems.

\section{Acknowledgements}

Our sincere acknowledgements to the WAEMU (West African Economic and Monetary Union), also known by its French acronym, UEMOA for funds.

\section{REFERENCES}

[1] ADAM J.C., 1953. Contribution à l'étude floristique des pâturages du Sénégal in «GROSMAIRE : Eléments de politique sylvopastorale au Sahel Sénégalais. Fascicule 12 ».-Dakar : Sect.Rech.Insp.Gén.Eaux et Forêts.AOF., 90 p.

[2] AKPO L.E., et GROUZIS M., 1996. Influence du couvert ligneux sur la régénération de quelques espèces ligneuses sahéliennes (Nord du Sénégal, Afrique occidentale). Webbia $50(2): 247-263$.

[3] AKPO L.E., 1993. Influence du couvert ligneux sur la structure et le fonctionnement de la strate herbacée en milieu sahélien. ORSTOM éd. (TDM, 93F2) Paris, 174p.

[4] AKPO E.L., et GROUZIS M. 2009. Effet des arbres sur la diversité de la végétation herbacée dans les parcours communautaires du Nord-Sénégal (Afrique de l'Ouest). Journal of Agriculture and Environnement for International Développement, 2009,103 (4) :271- 293.

[5] AKPO L.E., BANOIN M. et GROUZIS M., 2003. Effet de l'arbre sur la production et la qualité fourragères de la végétation herbacée : bilan pastoral en milieu sahélien. Revue Med.Vet., 2003, 154,10, 619 - 628.

[6] DIOUF M., 2000 Dynamique des écosystèmes sahéliens : Effets des microsites topographiques sur la diversité de la végétation ligneuse au Ferlo (Nord-Sénégal) DEA, UCAD-FST, Dakar, 44p. 
[7] BERHAUT J., 1967. Flore du Sénégal. Dakar : Librairie Clair Afrique. 485p.

[8] CHEVALLIER M.H., BENSAID S., DIALLO O.B., SAHKI R., GANABA S., SANOU J. et BOUGUEDOURA N., 2003. Biodiversité et multidisciplinarité : méthodologie pour zones arides. Bois et forets des tropiques, 2003, $\mathrm{N}^{\circ} \mathbf{2 7 6}$ (2), pp 33-41.

[9] DAJOZ R., 1985. Précis d'écologie. Ed. Dunod, Paris, 505p.

[10] DIAKITE B., 1992. Etude et gestion des pâturages naturels de la communauté rurale de Labgar (zone sylvo-pastorale du Sénégal). Thèse de doctorat d'état en Sciences et Médecine Vétérinaires.

[11] DIATTA S., DOUMA S., CHANONO M., BANOIN M., KABORE-ZOUNGRANA C.Y. ADAM T. et AKPO E.L., 2004. Caractéristiques de Maerua crassifolia Forsk., un ligneux fourrager des terres de parcours sahéliennes (Toukounouss-Filingué, Niger). Revue Africaine de santé et de Productions Animales, Vol.2 $N^{\circ} 2,2004$.

[12] DIOUF M., AKPO E.L., ROCHETEAU A., DO F., GOUDIABY V. et DIAGNE A.L., 2002. Dynamique du peuplement ligneux d'une végétation sahélienne au Nord Sénégal (Afrique de l'Ouest). Journal des sciences Vol. 2, $\mathrm{N}^{\circ} 1$ (2002).

[13] DIOP A.T.1989. Lles ressources ligneuses de la zone sylvo-pastorale du Sénégal: évolution, gestion et perspectives de développement. Communication présentée à l'atelier tenu 3 l'Université C.A.DIOP de Dakar sur "Foret,Environnement et Developpement" du 22 au 26 mai 1989.

[14] DOUMA, S., DIATTA, S., KABORE-ZOUNGRANA, C. Y., BANOIN, M., et AKPO, L. E. 2007. Caractérisation des terres de parcours sahéliennes: typologie du peuplement ligneux de la Station sahélienne Expérimentale de Toukounous au Niger. Journal des sciences, 7, 1-16.

[15] FALL-TOURE S., 1993. Valeur nutritive des fourrages ligneux, leur rôle dans la complémentation des fourrages pauvres des milieux tropicaux. Thèse doc. en Zootec. E.N.S.A. Montpellier 140p.

[16] FOURNIER C., 1995. Fonctionnement hydrique de six espèces ligneuses coexistant dans Savane sahélienne (région du Ferlo, Nord-Sénégal). TDM, ORSTOM Ed., Paris, 19, $166 \mathrm{p}$.

[17] GNING O.N., 2008. Caractérisation des ligneux fourragers dans les parcours communautaires de Khossanto (Kédougou, Sénégal oriental). Mémoire DEA, FST, UCAD (Sénégal), $55 p$.

[18] GROUZIS M., SICOT M., 1980. Une méthode d'étude phénologique des populations d'es pèces ligneuses sahéliennes in H.N. Le Houérou éd., les fourrages ligneux en Afrique, état actuel des connaissances. Symposium international, CIPEA, Addis Abeba :231-239.

[19] GUERIN H., 1991. Caractérisation des disponibilités fourragères ligneuses - Chapitre II. CCEBGXII - ST2, 26-69.

[20] LABIDI D. et GARITACELAYA J., 1997. Atil, l'arbre-brosse à dents des populations du Sahara. Revue forestière française.

[21] LAUVIE A., 2001. Recherche bibliographique dans le cadre du projet «impact des pratiques Humaines sur la conservation et la gestion in situ des ressources génétiques forestières: cas d'Acacia tortilis raddiana et de Balanites aegyptiaca ».Cirad-foret, Inapg, France, 25p. 
[22] LE HOUEROU H.N. ,1980. Le rôle des ligneux fourragers dans les zones Sahélienne et Soudanienne. In. Les fourrages ligneux en Afrique : état actuel des connaissances. Le Houerou H.N. CIPEA, Addis Abeba, Ethiopie 8-12 Avril, pp 85 - 101.

[23] LE HOUEROU H.N., 1989. The grazing land ecosystems of the African Sahel.Spriger Verlag, Berlin, 282p.

[24] MASHARABU T., NORET N., LEJOLY J., BIGENDAKO M.J. et BOGAERT J., 2010. Distribution et fréquence d'occurrence des plantes vasculaires du parc national de Ruvubu, Burundi. Biblio European Journal of Scientific Research ISSN 1450-216X Vol.43 No.4, pp.466-479.

[25] MICHEL P., 1973. Les bassins des fleuves Sénégal et Gambie. Etude géomorphologiques. Paris : ORSTOM, 752p.

[26] PIOT J. et DIAITE I., 1983. Etude du couvert ligneux. In.Système de production d'élevage au Sénégal. GRIZA/LAT, CTFT/Nogent/Marne, ISRA/LNERV, Dakar : 37p.

[27] POUPON H., 1980. Structure et dynamique de la strate ligneuse d'une steppe sahélienne au Nord du Sénégal. Trav. et Doc., ORSTOM éd., Paris, 351.

[28] ROBERTS-PICHETTE P. \& GILLESPIE L., 2002. Protocoles de suivi de la biodiversité Végétale terrestre. Le réseau d'évaluation et de surveillance écologiques Canada. Surhttp://www.eman se.ca/rese/ecotools/protocols/terrestrial/vegetation/glossary.html

[29] SARR O.,-2009. Caractéristiques des ligneux fourragers dans les parcours communautaires de Lour Escale (Département de Kaffrine, Sénégal). Mémoire DEA, FST, UCAD, 46p.

[30] SY, O. 2010. La transhumance transfrontalière, source de conflits au Ferlo (Sénégal). M@ ppemonde, 98(2010.2).

[31] THIAM I., 2008. Stratégies des exploitations agropastorales de Thieul (Ferlo-Sénégal) dans un contexte d'incertitude sur les ressources naturelles productives. Thèse de doctorat Université de Toulouse,394p.

[32] TOUNKARA B., 1991. Caractérisation des disponibilités fourragères ligneuses sur des parcours naturels sahéliens exploités par des bovins, ovins ou caprins. CEE-STD : 97p.

[33] TOURE I., 2010. Caractérisation de l'espace et des ressources des sites du Ferlo, Site de Tessékéré.eclis.get.obs-mip.fr/.../Touré_ibra_Tessékré_CIRAD_2010_12.pdf

[34] TRACOL Y., 2004. Etude des variations interannuelles de la production herbacée des Production herbacée des pâturages sahéliens : Exemple du Gourma Malien. Thèse de Doctorat en écologie des Ecologie des systèmes continentaux. Option Ecologie Tropicale \& Modélisation de la biosphère.UFR Sciences de la vie. Université de Toulouse III - Paul Sabatier.

[35] TROCHAIN J.,1940. Contribution à l'étude de la végétation du Sénégal. Mémoires de l'I.F.A.N., 2. Paris, Larose, 430p.

[36] VALENZA J. et DIALLO A.K., 1972. Etude des pâturages naturels du Nord du Sénégal Etude agrostologique, 1972, $\mathrm{N}^{\circ} \mathbf{3 4}, 311 \mathrm{p}$.

[37] VON MAYDELL H.J., 1990. Arbres et Arbustes du Sahel, leurs caractéristiques et leurs utilisations. Weikersheim, Allemagne, J. Margraf scientific book Verlag, 531 p. 